\title{
Awareness of Breast Cancer Risk Factors, Symptoms and Breast Self-Examination Among Omani Female Teachers A cross-sectional study
}

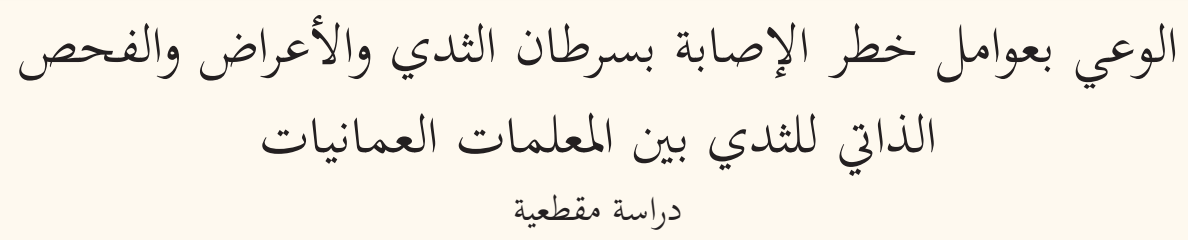

زوينة الإسماعيلية، خالد الناصري، أمل اليعقوبية، أحمد الشكيلي

ABSTRACT: Objectives: This study aimed to assess knowledge of breast cancer (BC) risk factors, warning signs and symptoms and breast self-examination (BSE) practice among Omani female teachers in Al-Dhahira Governorate. Methods: A cross-sectional sample of female teachers aged 20-50 years was collected from January to December 2018 from three wilayats (provinces) in Al-Dhahira-Ibri, Dhank and Yunqal. A questionnaire that included the Breast Cancer Awareness Scale and demographic characteristics was administered. Data were analysed using descriptive statistics, regression analysis and Pearson's Chi-square test. Results: A total of 478 female teachers were included in the study (response rate: $72.4 \%$ ). The majority of participants (60.5\%) had good overall knowledge about BC while $19.9 \%$ of participants had excellent overall knowledge. Only 9\% of participants demonstrating excellent knowledge of $\mathrm{BC}$ risk factors. More than half of the participants (56.1\%) reported excellent knowledge in screening methods. Unfortunately, only $57 \%$ of the female teachers indicated practising BSE. Knowledge of BC symptoms was closely divided between excellent and good levels ( 45.8 and $42.5 \%$, respectively). BSE practice was significantly $(P<0.05)$ correlated with overall knowledge of $\mathrm{BC}$ and its symptoms and screening methods, but not with knowledge of $\mathrm{BC}$ risk factors. Conclusion: This study revealed unsatisfactory overall knowledge of BC risk factors, symptoms, screening methods and BSE practice among female Omani teachers in Al-Dhahira Governorate. These findings constitute a challenge to healthcare providers to continue developing awareness of $\mathrm{BC}$ and providing health information to the public.

Keywords: Breast Cancer; Awareness; Knowledge; Breast Self-Examination; Risk factors; Signs and Symptoms; Oman.

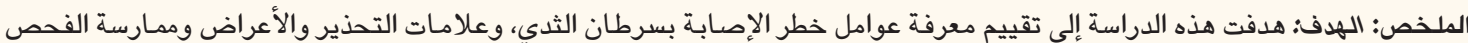

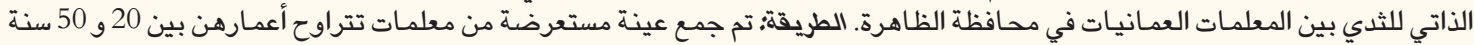

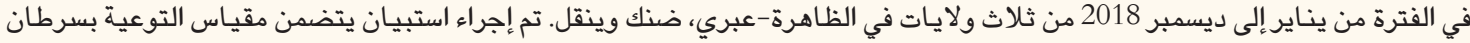

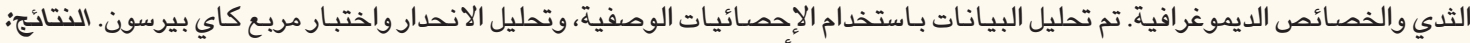

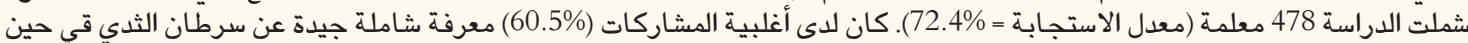

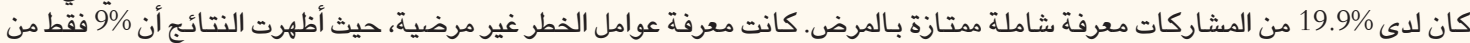

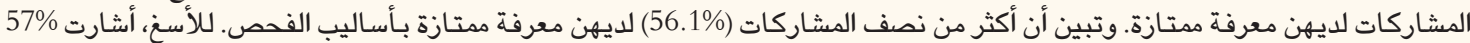

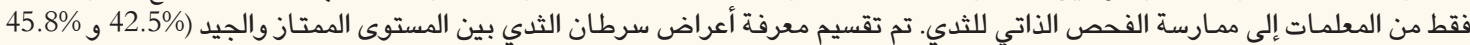

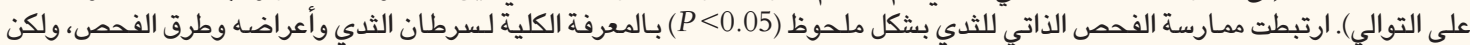

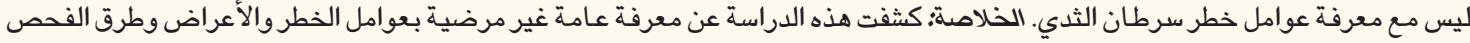

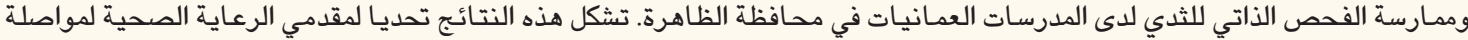
تطوير الوعي بسرطان الثدي وتوفير المعلومات الصدية الصحية لعامة الناس. الكلمات المفتاحية؛ سرطان الثدي. الوعي؛ المعرفه؛ الفحص الذاتي للثدي؛ عوامل الخطر؛ العلامات والأعراض؛ سلطنة عمان.

\footnotetext{
ADVANCES IN KNOWLEDGE

This is the first study to assess breast cancer (BC) awareness in rural areas in Oman.

The study revealed insufficient overall BC knowledge among female Omani teachers.

\section{Application to Patient Care}

Increased public awareness of BC's signs, symptoms and risk factors and breast self-examination (BSE) practice has a substantial impact on the incidence and outcomes of the disease.
} 
Early detection of BC leads to better response to therapy and subsequently improves survival rates.

The World Health Organization stresses promoting awareness of BC in the community and encourages early diagnosis of the disease in the primary care setting.

$\mathrm{B}$ REAST CANCER (BC) IS THE SECOND MOST common cancer worldwide and the most frequently diagnosed life-threatening cancer in women. In 2018, more than two million cases of BC were newly diagnosed among women., ${ }^{1,2}$ Case fatality rates from $\mathrm{BC}$ are higher in low- and middle-income countries than in most high-income countries. ${ }^{3-6}$ These observations have been attributed partially to a lack of awareness of BC risk factors and symptoms and a lack of practice of breast self-examination (BSE). ${ }^{4-6}$

Increased public awareness of $\mathrm{BC}$ is an important factor that has a substantial impact on early detection of the disease. Delayed BC diagnosis in developing countries has been associated with poor BC awareness and barriers to access healthcare services. Cancer that is diagnosed at an early stage is more likely to be treated successfully. ${ }^{7-9}$ In Oman, BC is the most common cancer in women, with a median age at diagnosis of 48 years, followed by thyroid cancer and colorectal cancer. ${ }^{10,11}$ In 2018, a total of 454 cases of BC were reported, representing $34.15 \%$ of total cancers in Omani women. ${ }^{1,2}$ This figure indicates a significant rise in BC cases in comparison to previous reports. ${ }^{1,11}$

According to several studies, increasing incidents of $\mathrm{BC}$ are associated with a combination of several risk factors including delayed childbirth, reduced incidence of breastfeeding, obesity, increased consumption of alcohol and a fatty diet, sedentary lifestyle, environmental pollution, long-term use of hormone replacement therapy (HRT) containing estrogen and progestin and contraceptive use. ${ }^{12-14}$ Other risk factors for BC have been attributed to molecular and genetic determinates. ${ }^{15}$

$\mathrm{BC}$ screening can be done by BSE, clinical breast examination $(\mathrm{CBE})$ and mammography. ${ }^{16}$ The effectiveness of $\mathrm{BSE}$ in reducing $\mathrm{BC}$ mortality remains controversial. Several studies have shown that trained women practising BSE does not reduce BC mortality. ${ }^{17,18}$ Other studies show that BSE may have a substantial effect in increasing $\mathrm{BC}$ awareness and could encourage women to seek $\mathrm{CBE}$, thus leading to earlier detection. ${ }^{19-21}$ The effectiveness of $\mathrm{CBE}$ is considered higher than BSE; however, the sensitivity of $\mathrm{CBE}$ is dependent on the amount of time taken to do an examination. ${ }^{22}$ Mammography is used as a sensitive screening method, particularly for women older than 40 years, but it is less effective for younger women. ${ }^{23}$

Studies to assess knowledge of BC and BSE practice are limited in Oman. Only two studies related to $\mathrm{BC}$ awareness to Oman have been published focusing on Muscat Governorate. ${ }^{24,25}$ Therefore, further studies are needed. This study aimed to ascertain the knowledge of risk factors, warning signs and symptoms of $\mathrm{BC}$, including BSE practice among Omani female teachers in Al-Dhahira Governorate.

\section{Methods}

In this cross-sectional study, stratified random sampling was used to select participants from a total of 22 governmental female schools in Al-Dhahira Governorate, Oman. The schools were selected according to the population size of each wilayat (province). Most of Al-Dhahira's population (75\%) are concentrated in Ibri, whereas Yanqul and Dhank represent only 25\% of the governorate's population. Questionnaires were distributed to 22 schools according to the proportion of population in each area (14 schools in Ibri, four schools in Yanqul and four schools in Dhank).

The sample size was calculated using online Sample Size Calculator. ${ }^{26}$ The needed sample size was estimated to be 675 female teachers. Schools were selected randomly from each stratum. The study cohort was selected because they were easily accessible and deemed to be educated.

All the participants were female teachers aged between $20-50$ years old. The study was conducted from January to December 2018. Non-Omani female teachers, women with a personal history of $\mathrm{BC}$ and incomplete questionnaires were excluded.

All participants were involved in the National Health Educational and Screening Programme initiated in 2010 by the Ministry of Health. School teachers were included in this programme through the School Health Section of the Directorate General of Health Services in Al-Dhahira Governorate. Regrettably, the success of this programme has not been assessed yet. The findings of this study may contribute to understanding the effectiveness of this programme.

Data were collected using a self-administered questionnaire which contained seven parts: (1) demographic data; (2) general BC knowledge; (3) presence of family history of $\mathrm{BC}$ and personal history of breast lump; (4-6) overall knowledge of BC (i.e. knowledge of risk factors, screening methods and symptoms of $\mathrm{BC})$; and (7) practice of BSE. The questionnaire was adapted from previously validated breast cancer awareness surveys. ${ }^{7,25,27}$ 
Risk factors for $\mathrm{BC}$ were assessed according to age, family history, having a personal history of $\mathrm{BC}$, early menarche, late menopause, having the first child after the age of 30, not breastfeeding, recent use of combined oral contraceptive (COC) or HRT, exposure to radiation, obesity, following a sedentary lifestyle, eating a diet high in fat, alcohol consumption or smoking and exposure to environmental pollution. The questionnaire was scored according to awareness of $\mathrm{BC}$ risk factors, with 0-6 items considered reflective of poor awareness, 7-12 considered indicative of good awareness and 13-16 items considered excellent awareness.

Women's knowledge about screening methods (i.e. CBE, BSE and mammography) was assessed by asking three separate questions associated with these methods. Poor awareness was reflected in a score of 0-1 items, good awareness was reflected in a score of two items and excellent awareness was reflected in a score of three items. Additionally, the questionnaire included eight questions about $\mathrm{BC}$ symptoms in relation to breast pain, painless or painful breast lumps, a change in the size of the breast, nipple or skin colour, bloody nipple discharge and a loss of weight and appetite. Levels of awareness of symptoms were classified as poor (aware of 0-3 items), good (aware of 4-6 items) and excellent (aware of 7-8 items).

Overall knowledge was calculated by adding the score of the three subscales (i.e. risk factors, symptoms and screening methods) and was interpreted as poor (aware of 0-11 items), good (aware of 12-20 items) and excellent (aware of 21-27 items).

Statistical Package for the Social Sciences (SPSS), Version 20 (IBM, Corp., Armonk, New York, USA) was used to analyse the data. Participants' demographic characteristics were summarised using means and standard deviation (SD) for continuous variables, and frequencies and percentages were used for categorical data. Inferential analyses (Pearson's Chi-square test and correlation and regression analyses) were also used to analyse the data. Descriptive statistics, including percentages, means and SD, were calculated.

To find the most important predictors of having better BC and BSE knowledge, a logistic regression analysis was used. Positive knowledge and practice of BSE were considered dependent variables, whereas age, educational level, income, family history of $\mathrm{BC}$, previous history of breast lump, knowledge of general facts about $\mathrm{BC}$ and geographical location were considered independent variables.

The study was approved by the Research and Ethics Committee at the Directorate General of Health Services of Al-Dhahira Governorate, Oman. Informed consent was obtained from all participants.

\section{Results}

A total of 478 female teachers completed the questionnaire (response rate: $72.4 \%$ ). The mean age of the participants was $33.3 \pm 5.5$ years old. As shown in Table 1 , the majority of participants (58.8\%) were $30-39$ years old, and most had a bachelor's degree (88.1\%). Most participants (72.3\%) were from Ibri, while $17.4 \%$ were from Dhank and 10.3\% were from Yanqul. More than half of the women (54.4\%) had a monthly income of 1,001-1,500 Omani rials (OMR), followed by an income of 500-1,000 OMR per month (39.1\%), and only $6.5 \%$ of the participants had an income $>1,500$ OMR per month. In total, $10.5 \%$ of participants had a positive family history of $\mathrm{BC}$ and $3.5 \%$ had a history of a breast lump [Table 1].

Table 1: Demographic characteristics of the included female teachers from Al-Dhahira Governorate $(\mathrm{N}=478)$

\begin{tabular}{lc} 
Variable & $\mathbf{n}(\%)$ \\
Age (years) & \\
$20-29$ & $131(27.4)$ \\
$30-39$ & $281(58.8)$ \\
$>40$ & $66(13.8)$ \\
Educational level & \\
Diploma & $46(9.6)$ \\
Bachelor's degree & $421(88.1)$ \\
Masters & $10(2.1)$ \\
PhD & $1(0.2)$ \\
Wilayat & \\
Ibri & $346(72.3)$ \\
Dhank & $83(17.4)$ \\
Yanqul & $49(10.3)$ \\
Income (OMR) & \\
500-1000 & $17(3.5)$ \\
1001-1500 & $454(95)$ \\
Family history of BC & $7(1.5)$ \\
Yes & $187(39.1)$ \\
No & $260(54.4)$ \\
Unknown & $31(6.5)$ \\
\hline Personal history of breast lump & $50(10.5)$ \\
\hline
\end{tabular}

$O M R=$ Omani riyal; $B C=$ breast cancer 
Table 2: Knowledge of risk factors for breast cancer among the included female teachers from Al-Dhahira Governorate $(\mathrm{N}=478)$

\begin{tabular}{|c|c|c|c|}
\hline \multirow[t]{2}{*}{ Risk factor } & \multicolumn{3}{|c|}{ n (\%) } \\
\hline & Yes & No & $\begin{array}{l}\text { I don't } \\
\text { know }\end{array}$ \\
\hline $\begin{array}{l}\text { Exposure to high } \\
\text { doses of radiation }\end{array}$ & $385(80.5)$ & $19(4)$ & $74(15.5)$ \\
\hline Family history of BC & $342(71.5)$ & $53(11.1)$ & 83 (17.4) \\
\hline $\begin{array}{l}\text { Personal history } \\
\text { of } \mathrm{BC}\end{array}$ & $329(68.8)$ & $43(9)$ & $106(22.2)$ \\
\hline Smoking & $322(67.4)$ & $43(9)$ & $113(23.6)$ \\
\hline $\begin{array}{l}\text { Environmental } \\
\text { pollution }\end{array}$ & $298(62.3)$ & $50(10.5)$ & $130(27.2)$ \\
\hline Alcohol & $281(58.8)$ & 38 (7.9) & $159(33.3)$ \\
\hline No physical exercise & $271(56.7)$ & 65 (13.6) & $142(29.7)$ \\
\hline High fat intake & $246(51.5)$ & $51(10.7)$ & $181(37.9)$ \\
\hline Obesity & $237(49.6)$ & $67(14)$ & $174(36.4)$ \\
\hline Use of HRT & $232(48.5)$ & $30(6.3)$ & $216(45.2)$ \\
\hline $\begin{array}{l}\text { Late menopause } \\
\text { (ending periods after } \\
\text { the age of } 55 \text { years) }\end{array}$ & $175(36.6)$ & $67(14)$ & $236(49.4)$ \\
\hline Use of COC & $154(32.2)$ & $67(14)$ & $257(53.8)$ \\
\hline $\begin{array}{l}\text { Delivery of first child } \\
\text { after } 30 \text { years of age }\end{array}$ & $118(24.7)$ & $123(25.7)$ & $237(49.6)$ \\
\hline Old age & $101(21.1)$ & $174(36.4)$ & $203(42.5)$ \\
\hline $\begin{array}{l}\text { Early menarche } \\
\text { (before } 12 \text { years old) }\end{array}$ & $76(15.9)$ & $121(25.3)$ & $281(58.8 \%)$ \\
\hline Not breastfeeding & $27(5.6)$ & $411(86)$ & $40(8.4)$ \\
\hline
\end{tabular}

Most participants believed that $\mathrm{BC}$ is the most common cancer in females and that early detection and treatment will lead to a favourable outcome $(86.2 \%$ and $94 \%$, respectively).

The most reported risk factor was exposure to a high dose of radiation (80.5\%), followed by a family history (71.5\%) and personal history of BC (68.8\%). Smoking and environmental pollution were reported by $67.4 \%$ and $62.3 \%$ of the participants, respectively, as risk factors for BC. Some participants reported hormonal factors as a risk factor including recent use of HRT (48.5\%), late menopause (36.6\%) and the use of COC (32.2\%). Not breastfeeding (5.6\%) was the least identified risk factor [Table 2].

Regarding the knowledge of screening methods, BSE was the most familiar method (88.1\%), followed by $\mathrm{CBE}(71.1 \%)$ and mammography (68\%). The most reported symptoms of $\mathrm{BC}$ were a painless breast lump $(82.2 \%)$, changes in breast size $(82 \%)$ and changes in the nipple (80.8\%). The least reported symptoms were
Table 3: Knowledge of screening methods and symptoms of breast cancer among the included female teachers from Al-Dhahira Governorate $(\mathrm{N}=478)$

\begin{tabular}{|c|c|c|c|}
\hline \multirow[t]{2}{*}{ Variable } & \multicolumn{3}{|c|}{ n (\%) } \\
\hline & Yes & No & $\begin{array}{l}\text { I don't } \\
\text { know }\end{array}$ \\
\hline \multicolumn{4}{|c|}{ Knowledge of screening methods } \\
\hline BSE & $421(88.1)$ & $22(4.6)$ & $35(7.3)$ \\
\hline CBE & $340(71.1)$ & $34(7.1)$ & $104(21.8)$ \\
\hline Mammography & $329(68)$ & $43(9)$ & $106(22.2)$ \\
\hline \multicolumn{4}{|l|}{ BC symptoms } \\
\hline Painless breast lump & $393(82.2)$ & $44(9.2)$ & $41(8.6)$ \\
\hline $\begin{array}{l}\text { Change in the size of } \\
\text { the breast }\end{array}$ & $392(82)$ & $32(6.7)$ & $54(11.3)$ \\
\hline Change in the nipple & $386(80.8)$ & $33(6.9)$ & $59(12.3)$ \\
\hline $\begin{array}{l}\text { Change in skin } \\
\text { colour }\end{array}$ & $366(76.6)$ & $37(7.7)$ & 75 (15.7) \\
\hline $\begin{array}{l}\text { Bloody nipple } \\
\text { discharge }\end{array}$ & $364(76.2)$ & $37(7.7)$ & 77 (16.1) \\
\hline Breast pain & 339 (70.9) & 89 (18.6) & $50(10.5)$ \\
\hline Painful breast lump & $334(69.9)$ & $93(19.5)$ & $51(10.7)$ \\
\hline $\begin{array}{l}\text { Loss of weight and } \\
\text { appetite }\end{array}$ & $240(50.2)$ & $74(15.5)$ & $164(34.3)$ \\
\hline
\end{tabular}

$B S E=$ breast self-examination; $C B E=$ clinical breast examination; $B C=$ breast cancer .

breast pain (70.9\%), a painful breast lump (69.9\%) and loss of weight and appetite (50.2\%) [Table 3]. The latter are considered symptoms of metastasis that appear at the end stage of the disease.

Overall knowledge of $\mathrm{BC}$ was calculated by adding the scores for knowledge of risk factors, screening methods and symptoms of $\mathrm{BC}$. The majority of participants $(60.5 \%)$ had good overall knowledge about BC, while $19.9 \%$ had an excellent overall knowledge. The rest of the participants (19.7\%) were categorised as having poor overall knowledge. About half of the participants (49.6\%) had good knowledge of $\mathrm{BC}$ risk factors, whereas $9 \%$ had scores reflective of excellent knowledge of risk factors. More than half of the participants $(56.1 \%)$ reported excellent knowledge of screening methods. Knowledge of BC symptoms (i.e., a painless breast lump; bloody nipple discharge; changes in breast skin colour, breast size or the nipple; breast pain; a painful lump; and loss of weight and appetite) was closely divided between excellent and good levels (45.8 and 42.5\%, respectively) [Table 4].

The main source of information about $\mathrm{BC}$ was received from health institutions $(64.7 \%)$ followed by the media (31.6\%); however, only $3.7 \%$ of the participants had obtained information from relatives and friends. 
Table 4: Overall knowledge of breast cancer among the included female teachers from Al-Dhahira Governorate $(\mathrm{N}=478)$

\begin{tabular}{lccc} 
Variable & \multicolumn{3}{c}{ n (\%) } \\
& Excellent & Good & Poor \\
$\begin{array}{l}\text { Overall } \\
\text { knowledge }\end{array}$ & $95(19.9)$ & $289(60.5)$ & $94(19.7)$ \\
$\begin{array}{l}\text { Knowledge of risk } \\
\text { factors }\end{array}$ & $43(9)$ & $237(49.6)$ & $198(41.4)$ \\
$\begin{array}{l}\text { Knowledge of } \\
\text { screening }\end{array}$ & $268(56.1)$ & $97(20.5)$ & $113(23.4)$ \\
$\begin{array}{l}\text { Knowledge of } \\
\text { symptoms }\end{array}$ & $219(45.8)$ & $203(42.5)$ & $56(11.7)$ \\
& & &
\end{tabular}

Table 5: Logistic regression analysis for the practice of breast self-examination among the included female teachers from Al-Dhahira Governorate $(\mathrm{N}=478)$

$\begin{array}{lcc}\text { Variable } & \text { Wald test } & \boldsymbol{P} \text { value } \\ \begin{array}{l}\text { Knowledge of BC screening } \\ \text { methods }\end{array} & 14.327 & 0.001 * \\ \text { Age } & 5.39 & 0.023 * \\ \text { Personal history of breast lump } & 6.34 & 0.042 * \\ \text { Wilayat } & 6.97 & 0.031 * \\ \begin{array}{l}\text { BC = breast cancer. } \\ \text { "Statistically significant. }\end{array} & & \\ \end{array}$

Multiple regression analysis using backward elimination method for overall knowledge of BC indicated a significant association with knowledge of the fact that early $\mathrm{BC}$ detection can lead to successful treatment $(P=0.001)$ and that $\mathrm{BC}$ is the commonest cancer among females $(P=0.001)$.

Among the participants, $57.5 \%$ indicated practicing BSE. The best timing for practicing BSE was assessed among participants. In total, $55.2 \%$ of them believed that the best time for practicing BSE was after menstruation while $18 \%$ replied that any time was a good time, $13.6 \%$ responded when a woman feels breast pain and $13.2 \%$ said before menstruation.

The majority of participants (54.2\%) attributed not practicing BSE to a lack of time, while $30.5 \%$ did not know how to perform BSE. Only 8.2\% considered BSE embarrassing and $7.1 \%$ of participants had a fear of finding $B C$ if they practiced BSE.

BSE was significantly correlated with overall knowledge of $\mathrm{BC}(P<0.05)$, screening methods $(P<0.001)$ and knowledge of symptoms $(P=0.014)$, but not with knowledge of risk factors $(P=0.23)$. The logistic regression model for practicing BSE showed the most powerful associations with knowledge of $\mathrm{BC}$ screening methods $(P=0.001)$, age $(P=0.023)$, having a personal history of a breast lump $(P=0.042)$, and geographical location $(P=0.031)$ [Table 5].
Table 6: Variables associated with overall knowledge and practice of breast self-examination among the included female teachers from Al-Dhahira Governorate $(\mathrm{N}=478)$

\begin{tabular}{|c|c|c|c|c|}
\hline \multirow[t]{2}{*}{ Variables } & \multicolumn{2}{|c|}{$\begin{array}{l}\text { Overall BC } \\
\text { knowledge }\end{array}$} & \multicolumn{2}{|c|}{ Practice of BSE } \\
\hline & $\begin{array}{l}\text { Chi- } \\
\text { square } \\
\text { value }\end{array}$ & $\begin{array}{c}P \\
\text { value }\end{array}$ & $\begin{array}{c}\text { Chi- } \\
\text { square } \\
\text { value }\end{array}$ & $\begin{array}{c}P \\
\text { value }\end{array}$ \\
\hline \multicolumn{5}{|c|}{ Demographic characteristic } \\
\hline Age & 3.11 & 0.540 & 7.27 & $0.026^{*}$ \\
\hline $\begin{array}{l}\text { Educational } \\
\text { level }\end{array}$ & 12.55 & 0.051 & 1.68 & 0.64 \\
\hline Province & 5.45 & 0.244 & 6.61 & $0.037^{*}$ \\
\hline Income & 6.08 & 0.193 & 2.09 & 0.35 \\
\hline \multicolumn{5}{|c|}{ Experience with BC } \\
\hline $\begin{array}{l}\text { Family history } \\
\text { of } B C\end{array}$ & 1.1 & 0.881 & 3.29 & 0.193 \\
\hline $\begin{array}{l}\text { Personal } \\
\text { history of } \\
\text { breast lump }\end{array}$ & 9.07 & 0.059 & 7.34 & $0.015^{*}$ \\
\hline \multicolumn{5}{|c|}{ Knowledge of general facts about $\mathrm{BC}$} \\
\hline $\begin{array}{l}\mathrm{BC} \text { is the } \\
\text { commonest } \\
\text { cancer among } \\
\text { females }\end{array}$ & 21.6 & $0.001^{*}$ & 5.79 & $0.016^{*}$ \\
\hline $\begin{array}{l}\text { Early detection } \\
\text { of } \mathrm{BC} \text { can lead } \\
\text { to successful } \\
\text { treatment }\end{array}$ & 21.57 & $0.001^{*}$ & 0.015 & 0.903 \\
\hline
\end{tabular}

Among demographic characteristics, age and geographical location were significantly associated with $\operatorname{BSE}(P=0.026$ and 0.037 , respectively) [Table 6]. General knowledge of $\mathrm{BC}$ as the most common cancer among females and having a personal history of breast lumps were significantly associated with practicing BSE ( $P=0.016$ and 0.015 , respectively). Knowledge of general facts about $\mathrm{BC}$ were significantly associated with overall knowledge of $\mathrm{BC}(P=0.001)$.

\section{Discussion}

This study confirms Omani women's unsatisfactory overall knowledge about $\mathrm{BC}$ risk factors and screening methods. ${ }^{24,25}$ Similar observations have previously been made in developed and developing countries, with participants showing poor understanding of major $\mathrm{BC}$ risk factors. ${ }^{27-32}$ Because the majority of female teachers involved in the current study had only goodto-poor knowledge of $\mathrm{BC}$, the results indicate that an educational programme is needed to increase awareness of $\mathrm{BC}$ risk factors. 
Unsatisfactory knowledge of BC risk factors was observed with risk factors such as non-breastfeeding, being overweight, having their first pregnancy after 30 years of age, having menopause after the age of 50 and doing less physical activity. This finding agrees with those reported by other studies. ${ }^{28,33}$ Moreover, knowledge of $\mathrm{BC}$ risk factors among Omani female teachers is different from that reported in previous studies conducted in the region. For instance, the current study showed that most participants (80\%) identified exposure to radiation as the highest risk factor for BC, whereas a previous study conducted in Muscat showed that only $24 \%$ of participants identified exposure to radiation as a risk factor. ${ }^{24}$ This observation also contrasted with a previous study done in Saudi Arabia, which showed that participants most often identified not breastfeeding as a BC risk factor, whereas it was the least reported risk factor in the current study. ${ }^{28}$

Similarly, contradictory findings were observed with overall knowledge of BC. Overall knowledge in Al-Dhahira Governorate was much higher than in the Muscat region. ${ }^{24}$ This difference may be attributed to differences in the study cohort and ongoing campaigns under the National Health Educational and Screening Programme in recent years. This programme may also have had a positive effect on knowledge of screening methods, since the majority of the current participants recognised the most common methods of $\mathrm{BC}$ screening (i.e., BSE, CBE and mammography). Participants' knowledge related to BSE was also satisfactory; most participants were aware of the importance of BSE. This finding is much higher than knowledge rates for BSE seen in some other studies. ${ }^{24,27-34}$ Nevertheless, Omani women's attitudes towards BSE need improvement, since only $57 \%$ of participants indicated practicing BSE. Other studies in Saudi Arabia reported 67.6\% of participants had never tried BSE. ${ }^{28}$ In contrast, a study in Uganda revealed that $76.5 \%$ of participants practiced BSE. ${ }^{29}$ On questioning current participants about reasons for not practicing BSE, 54.2\% reported not having time, $30.5 \%$ of participants stated that they did not know how to do it and a few reported fear of having $\mathrm{BC}$ and embarrassment at the process ( $8.2 \%$ and $7.1 \%$ respectively). These findings may be attributed to unawareness of practicing BSE. Although the usefulness of BSE as an appropriate method for early $\mathrm{BC}$ detection has been debated in recent years, the awareness of the importance of practicing BSE should be encouraged via an intensive health education programme. ${ }^{15,18-22}$

Income and level of education had no association with the level of knowledge or the practice of BSE. However, practicing BSE, knowledge of BC risk factors and symptoms were significantly correlated $(P<0.05)$ with knowledge of screening methods. This finding may be attributable to increased general awareness of BC and BSE among participants through healthcare providers. A similar study conducted in Iran revealed an association between educational level and knowledge of BC. ${ }^{31}$

The sources of information about $\mathrm{BC}$ in the current study included health institutions, followed by the media (i.e. TV, radio, and the Internet). This finding was inconsistent with previous studies conducted in Saudi Arabia, the United Arab Emirates, Egypt and Yemen, which showed that mass media (i.e. TV and radio) were the main sources of information about BC. ${ }^{28,33-36}$ Therefore, this study suggests that creating awareness of $\mathrm{BC}$ through media and campaigns needs to be strengthened in order to raise awareness of $\mathrm{BC}$ in the community.

The main limitations of this study are that the findings cannot be generalised to all females in the country because the female teachers included in this study were only from Al-Dhahira Governorate and mainly from Ibri Wilayat (72.4\%). Such a cohort may not be representative of all females in Oman and, to a lesser extent, from Al-Dhahira Governorate. In addition, the response rate of this study (72.4\%) should be considered a limitation because in survey research a response rate of $\geq 80 \%$ is expected.

\section{Conclusion}

The study revealed insufficient overall BC knowledge (especially knowledge of risk factors and BSE practice) among female Omani teachers. This finding signals a need for prompt interventions to raise awareness about $\mathrm{BC}$ and BSE among females. Healthcare providers need to continue educating the community about BC. The media, including TV and newspapers, also need to be involved in raising $\mathrm{BC}$ awareness. In addition, $\mathrm{BC}$ awareness should be included as a part of teacher training programmes at schools and colleges. Further studies involving a larger sample size and participants from different sectors are recommended.

\section{ACKNOWLEDGEMENTS}

The authors would like to thank all participating teachers in this study and research assistants for data collection during the study. We are thankful to the Directorate General of Education in $\mathrm{Al} \mathrm{Al-}$ Dhahira Governorate and all school principals for their cooperation during the study. We also thank the Oman Cancer Association Al-Dhahira Branch for their support during the study. We extend our sincere gratitude to Ms Elena Filimonova, Dr Joseph J. Moore 
Jr. and Ms Anna Snellen, for their excellent editing of the manuscript.

\section{CONFLICT OF INTEREST}

The authors declare no conflicts of interest.

\section{FUNDING}

No funding was received for this study.

\section{References}

1. Ferlay J, Ervik M, Lam F, Colombet M, Mery L, Piñeros M, et al. Global Cancer Observatory: Cancer Today. International Agency for Research on Cancer. From: https://gco.iarc.fr/today Accessed: Dec 2019.

2. Ferlay J, Colombet M, Soerjomataram I, Mathers C, Parkin DM, Piñeros $M$, et al. Estimating the global cancer incidence and mortality in 2018: GLOBOCAN sources and methods. Int I Cancer 2019; 144:1941-53. https://doi.org/10.1002/ijc.31937.

3. Bray F, Ferlay J, Soerjomataram I, Siegel RL, Torre LA, Jemal A. Global cancer statistics 2018: GLOBOCAN estimates of incidence and mortality worldwide for 36 cancers in 185 countries. CA Cancer J Clin 2018; 68:394-424. https://doi.org/10.3322/ caac. 21492.

4. Porter P. "Westernizing” women's risks? Breast cancer in lowerincome countries. N Engl J Med 2008; 358:213-6. https://doi. org/10.1056/NEJMp0708307.

5. Shulman LN, Willett W, Sievers A, Knaul FM. Breast cancer in developing countries: Opportunities for improved survival. J Oncol2010;2010:595167.https://doi.org/10.1155/2010/595167.

6. Jemal A, Bray F, Forman D, O'brien M, Ferlay J, Center M, et al. Cancer burden in Africa and opportunities for prevention. Cancer 2012; 118:4372-84. https://doi.org/10.1002/cncr.27410.

7. Rakkapao N, Promthet S, Moore MA, Solikhah S, Hurst, CP. Assessing breast cancer awareness in Thai women: Validation of the breast cancer awareness scale (B-CAS). Asian Pac J Cancer Prev 2017; 18:995-1005. https://doi.org/10.22034/APJ CP.2017.18.4.995.

8. Rojas K1, Stuckey A. Breast cancer epidemiology and risk factors. Clin Obstet Gynecol 2016; 59:651-72. https://doi.org/10.1097/ GRF.0000000000000239.

9. Sun YS, Zhao Z, Yang ZN, Xu F, Lu HJ, Zhu ZY, et al. Risk factors and preventions of breast cancer. Int J Biol Sci 2017; 13:1387-97. https://doi.org/10.7150/ijbs.21635.

10. Mehdi I, Monem EA, Al Bahrani BJ, Al Kharusi S, Nada AM, Al Lawati J, et al. Age at diagnosis of female breast cancer in Oman: issues and implications. S Asian J Cancer 2014; 3:101-6. https://doi.org/10.4103/2278-330X.130442.

11. Ministry of Health $(\mathrm{MoH})$. Annual report 2016: Sultanate of Oman, Muscat. From: https://www.moh.gov.om/documents /272928/1232802/20+years+Cancer+Incidence+in+Oman. pdf/737ea793-f805-e30c-d045-ea753fe522e5 Accessed: Dec 2019.

12. George SM, Bernstein L, Smith AW, Neuhouser ML, Baumgartner KB, Baumgartner RN, et al. Central adiposity after breast cancer diagnosis is related to mortality in the health, eating, activity, and lifestyle study. Breast Cancer Res Treat 2014; 146:647-55. https://doi.org/10.1007/s10549-014-3048-x.

13. Chan DS, Vieira AR, Aune D, Bandera EV, Greenwood DC, McTiernan A, et al. Body mass index and survival in women with breast cancer-Systematic literature review and metaanalysis of 82 follow-up studies. Ann Oncol 2014; 25:1901-14. https://doi.org/10.1093/annonc/mdu042.
14. Forouzanfar MH, Foreman KJ, Delossantos AM, Lozano R, Lopez AD, Murray CJL, et al. Breast and cervical cancer in 187 countries between 1980 and 2010: A systematic analysis. Lancet 2011; 378:1461-84. https://doi.org/10.1016/S01406736(11)61351-2

15. World Health Organization. Guide to cancer early diagnosis. From: https://apps.who.int/iris/bitstream/handle/10665/25450 0/9789241511940-eng.pdf?sequence=1 Accessed: Dec 2019

16. Gómez-Flores-Ramos L, Castro-Sánchez A, Peña-Curiel O, Mohar-Betancourt A. Molecular biology in young women with breast cancer: From tumor gene expression to DNA mutations. Rev Invest Clin 2017; 69:181-92. https://doi.org/10.24875/RIC.17 002225 .

17. Thomas DB, Gao DL, Ray RM, Wang WW, Allison CJ, Chen FL, et al. Randomized trial of breast self-examination in Shanghai: Final results. J Natl Cancer Inst 2002; 94:1445-57. https://doi. org/10.1093/jnci/94.19.1445.

18. Hackshaw AK, Paul EA. Breast self-examination and death from breast cancer: A meta-analysis. Br J Cancer 2003; 88:1047-53. https://doi.org/10.1038/sj.bjc.6600847.

19. Thornton H, Pillarisetti RR. 'Breast awareness' and 'breast selfexamination' are not the same. What do these terms mean? Why are they confused? What can we do? Eur J Cancer 2008; 44:2118-21. https://doi.org/10.1016/j.ejca.2008.08.015.

20. Al-Khamis NK. Low awareness of breast cancer and considerable barriers to early presentation among Saudi women at a primary care setting. J Cancer Educ 2018; 33:391-7. https://doi.org/10.1 007/s13187-016-1119-x.

21. Hurst CP, Promthet S, Rakkapao N. Factors associated with breast cancer awareness in Thai women. Asian Pac J Cancer Prev 2019; 20:1825-31. https://doi.org/10.7314/apjcp.2016.17.2.851.

22. McDonald S, Saslow D, Alciati MH. Performance and reporting of clinical breast examination: A review of the literature. CA Cancer J Clin 2004; 54:345-61. https://doi.org/10.3322/canjcl in.54.6.345.

23. Gøtzsche PC, Jørgensen KJ. Screening for breast cancer with mammography. Cochrane Database Syst Rev 2013; 6:CD001877. https://doi.org/10.1002/14651858.CD001877.pub5.

24. Renganathan L, Ramasubramaniam S, Al-Touby S, Seshan V, Al-Balushi A, Al-Amri W, et al. What do Omani women know about breast cancer symptoms? Oman Med J 2014; 29:408-13. https://doi.org/10.5001/omj.2014.110.

25. Al Junaibi RM, Khan SA. Knowledge and awareness of breast cancer among university female students in Muscat, Sultanate of Oman - A pilot study. J Appl Pharm Sci 2011; 1:146-9.

26. Creative Research Systems. Sample size calculator. From: https:// www.surveysystem.com/sscalc.htm Accessed: Dec 2019.

27. Rakkapao N, Promthet S, Moore MA, Hurst CP. Development of a breast cancer awareness scale for Thai women: Moving towards a validated measure. Asian Pac J Cancer Prev 2016; 17:851-6. https://doi.org/10.7314/apjcp.2016.17.2.851.

28. Dandash KF, Al-Mohaimeed A. Knowledge, attitudes, and practices surrounding breast cancer and screening in female teachers of Buraidah, Saudi Arabia. Int J Health Sci (Qassim) 2007; 1:61-71.

29. Galukande M, Wabinga H, Mirembe F, Karamagi CD, Aseae A. Breast cancer risk factors among Ugandan women at a tertiary hospital: A case-control study. Oncology 2016; 90:356-62. https://doi.org/10.1159/000445379.

30. Leslie NS, Deiriggi P, Gross S, DuRant E, Smith C, Veshnesky JG. Knowledge, attitudes, and practices surrounding breast cancer screening in educated Appalachian women. Oncol Nurs Forum 2003; 30:659-67. https://doi.org/10.1188/03.ONF.659-667.

31. Breslow RA, Sorkin JD, Frey CM, Kessler LG. Americans' knowledge of cancer risk and survival. Prev Med 1997; 26:170-7. https://doi.org/10.1006/pmed.1996.0136. 
32. Izanloo A, Ghaffarzadehgan $\mathrm{K}$, Khoshroo F, Haghiri ME, Izanloo $\mathrm{S}$, Samiee M, et al. Knowledge and attitude of women regarding breast cancer screening tests in Eastern Iran. E Cancer Med Sci 2018; 12:806. https://doi.org/10.3332/ecancer.2018.806.

33. Radi SM. Breast cancer awareness among Saudi females in Jeddah. Asian Pac J Cancer Prev 2013; 14:4307-12. https://doi. org/10.7314/apjcp.2013.14.7.4307.

34. Rahman SA, Al-Marzouki A, Otim M, Khalil Khayat NEH, Yousuf R, Rahman P. Awareness about breast cancer and breast self-examination among female students at the University of Sharjah: A cross-sectional study. Asian Pac J Cancer Prev 2019; 20:1901-8. https://doi.org/10.31557/APJCP.2019.20.6.1901.
35. Boulos DN, Ghali RR. Awareness of breast cancer among female students at Ain Shams University, Egypt. Glob J Health Sci 2013; 6:154-61. https://doi.org/10.5539/gjhs.v6n1p154.

36. Ahmed BA. Awareness and practice of breast cancer and breast-self examination among university students in Yemen. Asian Pac J Cancer Prev 2010; 11:101-5. 